\title{
TLC Separation of Cephalosporins on Stannic Arsenate Layers
}

\author{
Ajay Gupta \& Jayshree Dassani \\ Department of Applied Sciences, SR Group of Institutions, Jhansi
}

\begin{abstract}
The chromatographic behaviour of some cephalosporins has been studied on synthetic stannic arsenate layers using citrate and borate buffers as mobile phases. Several ternary and quaternary separations have been achieved. The utility of these separations has been demonstrated for estimation of cephalosporins in blood serum from patients.This method used is simple, rapid, reproducible and can also be applied in the separation and determination of cephalosporins in other biological samples. The limit of detection was found to be $0.20 \mu \mathrm{g} / \mathrm{l}$.

Key Words: TLC, Cephalosporins, Stanic arsenate
\end{abstract}

\section{Introduction}

The use of inorganic ion exchangers as adsorbents in thin layer chromatography has afforded promising results in the separation of metal ions, anions [1-4], organic compounds [5,6], phenols [7] and organic acids [8]. The widespread application of ion-exchange resins for separating and purifying amino acids from protein hydrolysis has received considerable attention [9,10]. Stannic arsenate has been used for TLC because it has been found to be quite stable in acids, bases, and common organic solvents; it has been used for separation of metal ions [11], anions [12], and amino acids [13].Addition of inorganic salts to conventional adsorbents and use of organic and inorganic solvents as mobile phases has been reported to result in improved separations of some pharmaceutical products compared with the untreated adsorbent [14]. Double hydroxide adsorbent layers have been used for TLC separation of cephalosporins [15]. The cephalosporin anti-biotics are a large family of therapeutically useful compounds

Sporadic publications on the identification of cephalosporin anti-biotics by densitometry on hydrocarbon-impregnated silica gel HPTLC plates have appeared in the literature [16-17] and TLC of cephalosporins has also been performed on silanized silica gel [18-19]. In this work we have reported the utility of stannic arsenate and simple mobile phases for separation of cephalosporins and their subsequent quantitative determination in the blood serum of patients.

\section{Chemicals}

\section{Experimental}

Sodium arsenate(Loba Chemic,India),Stenic Chloride(Loba Chemic,India),Methanol (AR grade), citric acid, sodium hydroxide, potassium di-hydrogen phosphate, ammonia solution, borax, sodium bicarbonate, ferric ammonium sulphate, and hydroxylamine hydrochloride were from Merck (Mumbai, India) . Boric acid was from Ranbaxy (S.A.S. Nagar, India). Ni-ckel(II) chloride hexahydrate was from Qualigens Fine Chemical (Mum-bai, India).

\section{Samples}

Cefaclor was from Aristo pharmaceuticals (Nani Daman, Mumbai, India), ceftriaxone from Otomotive Products (Navi Mumbai, India), cefta-zidime from Biochem Pharmaceuticals (Mumbai, India), cefoperazone from

Unimed Technologies (Halol, Gujarat, India), cefotaxime from Starry Health Care (Vikhroli (W) Mumbai, India), cefadroxil from Comed Chemicals (Baroda, Gujarat, India), and cephalexin from Glaxo India (Mumbai, In-dia). The structures of the compounds are shown in Fig. 1.

\section{Preparation of Ion- exchange material and development of TLC plates}

Stenic arsenate ion-exchanger was prepared by mixing 0.5 molar sodium arsenate with 0.5 molar stenic chlotide in 1:1 ratio at $\mathrm{pH} 10.0$ and subsequent addition of $0.1 \mathrm{M} \mathrm{HCl}$. The resulting precipitate was digested at room temp. for 24 hours,filtered by suction and then dried in an oven at $40 \pm 50$ C.The material obtained was cracked in dimineralized water,mixed with $1 \mathrm{M}$ Nitric ad. and kept for over night so that it is converted in to protonated form.It was washed with demineralized water to remove exciss ad. and finally dried in an oven at $40^{\circ} \mathrm{C}$

The TLC plates were prepared in the usual manner from demineralized water. The slurry was spread over TLC plates with $0.2 \mathrm{~mm}$ thickness and dried in air overnight, and activated at $60^{\circ} \mathrm{C}$ for $1 \mathrm{~h}$ before spot application. 


\section{Solvent System used}

At least 20 different solvents were used as mobile phases but sepa-ration of cephalosporins on stannic arsenate was achieved solely by use of citrate and borate buffers of different $\mathrm{pH}$. The mobile phases used are listed in Table I.

\section{Qualitative Separations in synthetic mixtures}

For qualitative studies solutions $\left(1.0 \mathrm{mg} \mathrm{mL}^{-1)}\right.$ of each cephalospo-rin in DMW were applied at one end of the plate. The glass plates $(18 \mathrm{~cm} \times 20 \mathrm{~cm})$ were developed, at room temperature $\left(25 \pm 3^{\circ} \mathrm{C}\right)$, in rectangular chambers $(20 \mathrm{~cm} \times 22 \mathrm{~cm} \times 9 \mathrm{~cm})$ previously equilibrated by conditioning with mobile phase for at least $1 \mathrm{~h}$. The time required for chromatographic development of the plates varied with the mobile phase used. After development plates were dried with a stream of cold air and the spots were visualized.

by placing the plates in a chamber of iodine vapour. Brown spots on the plate revealed the location of the compounds. $h R_{\mathrm{F}}$ values were calculated by means of the formula:

$$
h R_{\mathrm{F}}=\frac{\text { distance travelled by the geometrical centre of the solute spot }}{\text { distance travelled by solvent front from the point of application }} \times 100
$$

The $h R_{\mathrm{F}}$ values obtained are listed in Table II.

\section{Quantitative Separations}

For quantitative work, stock solutions of cephalosporins were pre-pared in demineralized water. Solutions of different cephalosporins were mixed, spotted by means of a microsyringe, and developed with a selected mobile phase. A pilot plate was run simultaneously to visualise exact position of the spot on the TLC plate. The regions containing the cephalosporins were scraped from the plates, mixed in demineralized water and then filtered. The clear solution containing the cephalosporin content of each spot was then analysed by a spectrophotometric method [20-24]. Results are shown in Table III.

\section{Quantitative Estimation of Cephalosporins in Blood Serum Samples}

Anhydrous sodium sulphate $(40 \mathrm{~g})$ and ethanol $(95 \%, 2 \mathrm{~mL})$ were mixed with $10 \mathrm{~mL}$ of oxalate blood. The mixture was centrifuged and after 2.5 hours the supernatant liquid was decanted. Because of the presence of sodium sulphate and alcohol, water was eliminated. Finally the mixture was mixed with diethyl ether for 45 $\mathrm{min}$. The ether layer was separated and the mixture was concentrated to approximately $0.10 \mathrm{~mL}$ under vacuum at $50^{\circ} \mathrm{C}$. Blood serum samples from different patients were collected and analysed for specific antibiotics by a spectrophotometric method. Known amount of the concentrated solution of cefalosporine was then applied to the TLC plates and the plates were developed with an appropriate mobile phase. The region containing the spot was scraped from the plate, mixed with demineralised water, and same procedure was applied as in quantitative separation.

\section{Results And Disicussion}

Antibiotics are chemically defined reproducible chemical substan-ces produced in and isolated from living cells, or are chemical or biological derivatives of these [25]. Non-specific methods for analysis of antibiotics, for example microbiological and spectrophotometric methods, do not differentiate between structurally similar byproducts from the synthesis or degradation of the antibiotics of interest. More specific methods such as TLC, GC, and HPLC that differentiate among different structures are preferable for analysis of antibiotics [26]. Because of the unstable nature of antibiotics, decomposition of the drugs or polymerization can occur during chromatography, although this occurs less in TLC than in paper chromatography [27].

Stannic arsenate is regarded as quite stable, amorphous, and hydrated to a variable extent. TLC plates are, therefore, activated at $60^{\circ} \mathrm{C}$ to desorb physically bonded water. The spots were detected by placing the TLC plates in an iodine vapour chamber. The iodine vapour dissolves in or forms weak charge transfer complexes with organic compounds and the cephalosporins show up as brown spots on a pale yellow background within few minutes. After marking the zones for further reference exposure of the plates to air causes the iodine to sublime and the spots fade. The $h R_{\mathrm{F}}$ values of the different cephalosporins after chromatography with mobile phases S1 to S9 are shown in Table II. It is clear from the $h R_{\mathrm{F}}$ values that cefaclor, which contains a Cl group, has higher $h R_{\mathrm{F}}$ values for most of the mobile phases than cephalexin $\left(\mathrm{OCH}_{3}\right.$ group) or cefadroxil $\left(\mathrm{CH}_{3}\right.$ group). This might be because of the negative inductive effect $-\mathrm{Cl}^{-}$has a stronger negative inductive effect than $\mathrm{OCH}_{3}$ (i.e. attracts electrons more strongly).

It was found that the behaviour of cefoperazone was peculiar in almost all of the mobile phases except ammonia and potassium dihydrogen phosphate. The positive inductive effects of the methyl and ethyl groups in 
cefoperazone reduce chemical interaction with the mobile phase and hence migration is suppressed. On the other hand, the presence of the $\mathrm{Na}^{+}$ion in cefotaxime, ceftazidime, and cefoperazone facilitates release of an electron, leading to the formation of polar compounds that are highly soluble in water and, therefore, of low $R_{\mathrm{F}}$ in acidic media and high $R_{\mathrm{F}}$ value in basic media, as expected.

It is apparent from Table II that separation of most of the cephalo-sporins is poor with the ammonia mobile phase, probably because of solvation of the alkali metals by the ammonia molecule. The exceptional behaviour of ceftriaxone chromatographed with ammonia and potassium dihydrogen phosphate enables selective separation of this antibiotic from the other cephalosporins. On the basis of the different $R_{\mathrm{F}}$ values of the cephalosporins when chromatographed with different mobile phases it is possible to achieve some important binary and ternary quantitative sepa-rations on stannic arsenate layers in a few minutes only. It is worth noting one advantage of using stannic arsenate layers - the possibility of selective separation of some components of a synthetic mixture of cephalosporins. The results are reported in Table III.

This TLC method is simple, rapid, selective, reproducible, and applicable to identification and separation of cephalosporins. The practical utility of this method was demonstrated by quantitative identification of common cephalosporins in serum samples from patients .The results are summarized in Table IV. The percentage recovery, accuracy, and reproducibility of the method were checked statistically.
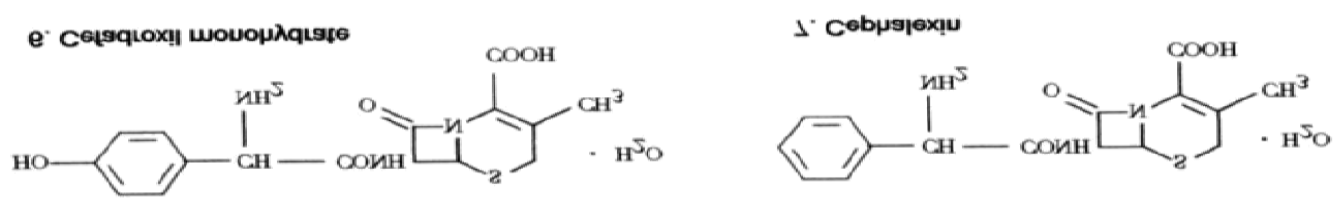

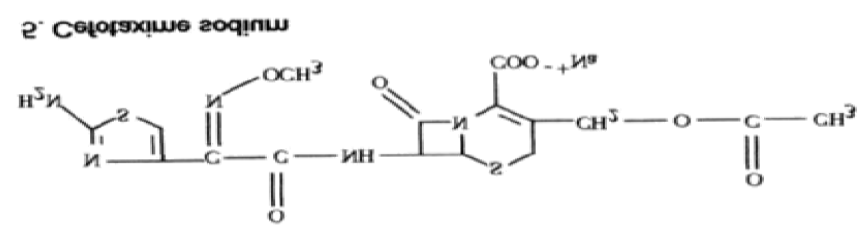

\section{f' Cę̧obetssoue aoq!nu}

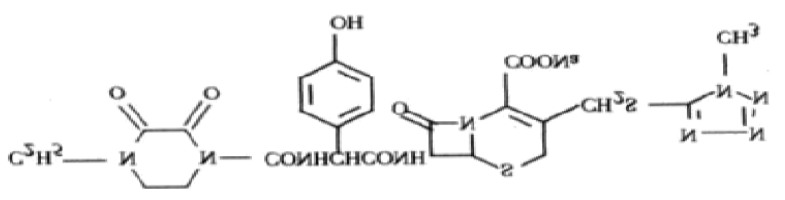

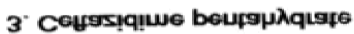

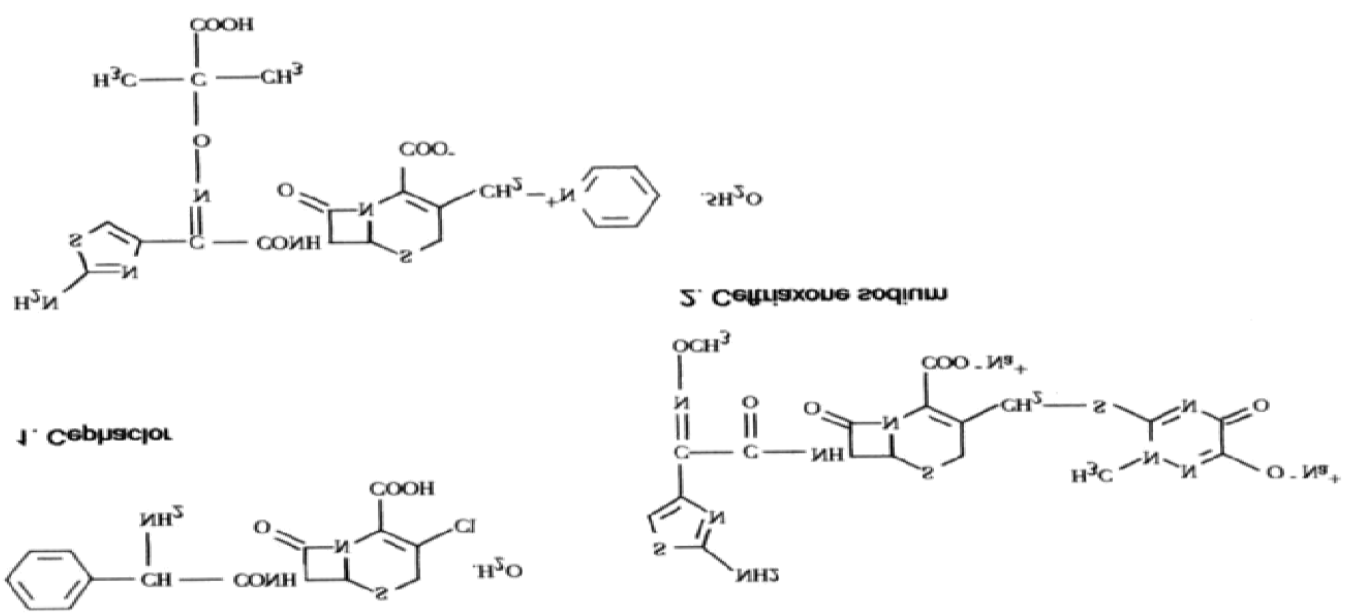

Fig. 1. The molecular structures of the cephalosporins studied 
Table I

Solvent System used

\begin{tabular}{|c|c|c|}
\hline Components & $\mathrm{pH}$ & Abbreviation \\
\hline $0.2 \mathrm{M}$ Boric acid & 1.20 & S1 \\
\hline Citrate buffer $(0.2 \mathrm{M}$ citric acid $+0.2 \mathrm{M}$ sodium hydroxide $)$ & 3.10 & $\mathrm{~S} 2$ \\
\hline Citrate buffer $(0.2 \mathrm{M}$ citric acid $+0.2 \mathrm{M}$ sodium hydroxide $)$ & 4.15 & S3 \\
\hline Citrate buffer $(0.2 \mathrm{M}$ citric acid $+0.2 \mathrm{M}$ sodium hydroxide $)$ & 5.55 & $\mathrm{~S} 4$ \\
\hline Borate buffer $(0.2 \mathrm{M}$ boric acid $+0.2 \mathrm{M}$ sodium hydroxide $)$ & 9.20 & S5 \\
\hline Borax & 9.22 & S6 \\
\hline Borate buffer $(0.2 \mathrm{M}$ boric acid $+0.2 \mathrm{M}$ sodium hydroxide $)$ & 10.23 & S7 \\
\hline Aqueous ammonia (30\%) & 13.35 & S8 \\
\hline $0.1 \mathrm{M}$ Potassium dihydrogen phosphate & 5.35 & S9 \\
\hline
\end{tabular}

Table II

$h R_{\mathrm{f}}$ values of the cephalosporins on stannic arsenate layers developed with different mobile phases

\begin{tabular}{|c|l|c|c|c|c|c|c|c|c|c|}
\hline No. & Cephalosporin & S1 & S2 & S3 & S4 & S5 & S6 & S7 & S8 & S9 \\
\hline 1 & Cephalexin & 87.55 & 72.42 & 11.24 & 77.27 & 94.50 & 84.61 & 87.50 & 43.32 & 44.40 \\
\hline 2 & Cefadroxil & 42.90 & 72.32 & 0.00 & 77.27 & 43.82 & 15.30 & 38.40 & 61.35 & 55.50 \\
\hline 3 & Cefaclor & 99.95 & 87.27 & 76.73 & 85.50 & 99.40 & 99.50 & 97.85 & 71.52 & 52.50 \\
\hline 4 & Cefotaxime & 85.54 & 0.00 & 76.47 & 0.00 & 87.50 & 92.50 & 74.80 & 73.83 & 65.42 \\
\hline 5 & Ceftriaxone & 0.00 & 0.00 & 0.00 & 0.00 & 0.00 & 0.05 & 0.10 & 62.55 & 17.35 \\
\hline 6 & Ceftazidime & 0.00 & 0.00 & 0.00 & 0.00 & 45.00 & 98.45 & 3050 & 74.55 & 71.50 \\
\hline 7 & Cefoperazone & 58.15 & 0.00 & 0.00 & 31.35 & 43.75 & 37.40 & 44.55 & 75.80 & 70.40 \\
\hline
\end{tabular}

Table III

Quantitative separations of cephalosporins from synthetic mixtures on stannic oxide layers

\begin{tabular}{|c|c|c|c|c|c|c|c|}
\hline No. & $\begin{array}{c}\text { Separations } \\
\text { achieved }\end{array}$ & $\begin{array}{c}\text { Amount } \\
\text { taken }(\mu \mathrm{g})\end{array}$ & $\begin{array}{c}\text { Amount } \\
\text { found }(\mu \mathrm{g})^{\mathrm{a}}\end{array}$ & $\begin{array}{r}\text { Recovery } \\
(\%) \\
\end{array}$ & Error $(\%)$ & $S D$ & $\begin{array}{l}\text { Mobile } \\
\text { phase }^{b}\end{array}$ \\
\hline \multirow{3}{*}{1} & Cefaclor & 50.00 & 49.50 & 99.00 & -1.00 & 0.018 & \multirow{3}{*}{$\mathrm{S} 2$} \\
\hline & Ceftriaxone & 50.00 & 50.00 & 100.00 & 0.00 & 0.070 & \\
\hline & Cefadroxil & 50.00 & 49.85 & 99.70 & -0.30 & 0.007 & \\
\hline \multirow{3}{*}{2} & Ceftriaxone & 50.00 & 50.00 & 100.00 & 0.00 & 0.079 & \multirow{3}{*}{ S4 } \\
\hline & Cefoperazone & 50.00 & 50.04 & 100.08 & 0.08 & 0.048 & \\
\hline & Cephalexin & 50.00 & 50.22 & 100.44 & 0.44 & 0.062 & \\
\hline \multirow{3}{*}{3} & Ceftazidime & 50.00 & 49.72 & 99.44 & -0.56 & 0.090 & \multirow{3}{*}{ S1 } \\
\hline & Cefotaxime & 50.00 & 49.73 & 99.46 & -0.54 & 0.065 & \\
\hline & Cefadroxil & 50.00 & 49.61 & 99.22 & -0.78 & 0.097 & \\
\hline \multirow{3}{*}{4} & Cefotaxime & 50.00 & 49.83 & 99.66 & -0.34 & 0.014 & \multirow{3}{*}{ S9 } \\
\hline & Cefadroxil & 50.00 & 49.72 & 99.44 & -0.56 & 0.013 & \\
\hline & Ceftriaxone & 50.00 & 50.01 & 100.02 & 0.02 & 0.008 & \\
\hline \multirow{3}{*}{5} & Cefaclor & 50.00 & 49.50 & 99.00 & -1.00 & 0.017 & \multirow{3}{*}{ S3 } \\
\hline & Ceftriaxone & 50.00 & 50.0 & 100.00 & 0.00 & 0.083 & \\
\hline & Cephalexin & 50.00 & 50.18 & 100.36 & 0.36 & 0.021 & \\
\hline \multirow{4}{*}{6} & Cefaclor & 50.00 & 49.50 & 99.00 & -1.00 & 0.017 & \multirow{4}{*}{ S6 } \\
\hline & Ceftriaxone & 50.00 & 50.00 & 100.00 & 0.00 & 0.070 & \\
\hline & Cefoperazone & 50.00 & 49.92 & 99.84 & -0.16 & 0.168 & \\
\hline & Cefadroxil & 50.00 & 49.65 & 99.30 & -0.70 & 0.097 & \\
\hline \multirow{4}{*}{7} & Ceftriaxone & 50.00 & 50.00 & 100.00 & 0.00 & 0.079 & \multirow{4}{*}{ S5 } \\
\hline & Ceftazidime & 50.00 & 49.73 & 99.46 & -0.54 & 0.183 & \\
\hline & Cefotaxime & 50.00 & 49.84 & 99.68 & -0.32 & 0.014 & \\
\hline & Cephalexin & 50.00 & 49.50 & 99.00 & -1.00 & 0.013 & \\
\hline
\end{tabular}


${ }^{a}$ Average from five replicate determinations

${ }^{\mathrm{b}} \mathrm{S} 1$, Boric acid ( $\mathrm{pH} 1.25$ ); S2, citrate buffer ( $\left.\mathrm{pH} 3.15\right)$; S3, citrate buffer ( $\left.\mathrm{pH} 4.05\right)$; S4, citrate buffer ( $\mathrm{pH} 5.05$ ); $\mathrm{S} 5$, borate buffer ( $\mathrm{pH} 9.10$ ); S6, borax buffer ( $\mathrm{pH} 9.18$ ); S9, po-tassium dihydrogen phosphate ( $\mathrm{pH}$ 5.30)

Table IV

Quantitative separations of cephalosporins from samples of patients' serum

\begin{tabular}{|c|c|c|c|c|c|c|}
\hline $\begin{array}{c}\text { Serum } \\
\text { sample } \\
\text { no. }\end{array}$ & Cephalosporin & $\begin{array}{r}\text { Amount taken } \\
(\mu \mathrm{g})\end{array}$ & $\begin{array}{r}\text { Amount found } \\
(\mu \mathrm{g})^{\mathrm{a}}\end{array}$ & $\begin{array}{c}\text { Recovery } \\
(\%)\end{array}$ & $S D$ & $\begin{array}{l}\text { Mobile } \\
\text { phase }^{b}\end{array}$ \\
\hline 1 & Cefaclor & 50 & 49.90 & 99.80 & 0.05 & S 1 \\
\hline 2 & Cefotaxime & 100 & 49.95 & 99.90 & 0.125 & S 6 \\
\hline 3 & Ceftriaxone & 100 & 49.20 & 9840 & 0.038 & S 8 \\
\hline 4 & Ceftazidime & 50 & 49.45 & 98.90 & 0.022 & S 6 \\
\hline
\end{tabular}

${ }^{\mathrm{a}}$ Average from four replicate determinations

${ }^{\mathrm{b}} \mathrm{S} 1$, boric acid ( $\mathrm{pH} 1.25$ ); S6, borax buffer ( $\left.\mathrm{pH} 9.18\right)$; $\mathrm{S} 8$, aqueous ammonia ( $\left.\mathrm{pH} 13.55\right)$

\section{References}

[1] S.D. Sharma, T.D. Sharma, and B.C. Sethi, J. Liq. Chromatogr., 6, 1253 (1983)

[2] N.S. Sethi, R.P.S. Rajput, and N.K. Agarwal, Anal. Lett., 18, 481 (1985)

[3] S.A. Nabi, W.U. Farooqui, and N. Rahman, J. Planar Chromatogr., 7, 38 (1994)

[4] G. Vanik and S.W. Hussain, Anal. Sci., 16, 1079 (2000)

[5] S.A. Nabi, W.U. Farooqui, and Z.M. Siddiqui, J. Liq. Chromatogr., 6, 109 (1983)

[6] S.A. Nabi, W.U. Farooqui, and N. Rahman, Chromatographia, 20, 109 (1985)

[7] K. Sahil, S.K. Dabral, and K.P.S. Muktawat, J. Indian Chem. Soc., 79(9), 739 (2002)

[8] K. Sahil, S.K. Dabral, and K.P.S. Muktawat, J. Indian Chem. Soc., 78, 374 (2001)

[9] L. Lepri, P.G. Desideri, and D. Heimler, J. Chromatogr., 268, 493 (1983)

[10] S.D. Sharma, H. Sharma, and S.C. Sharma, Chem. Environ. Res., 11, 179 (2002)

[11] N. Zattrezie-Renault, J. Inorg. Nucl. Chem., 40, 539 (1978)

[12] A.K. Sen and U.C. Ghosh, J. Liq. Chromatogr., 3, 31 (1980)

[13] S.A. Nabi and A. Sikarwar,Acta . Chromatogr.,9,123-132(1999)

[14] J.A. Manthey and M.E. Amundson, J. Chromatogr., 19, 522 (1965)

[15] S.Z. Qureshi, R.M.A.Q. Jamhour, and N. Rahman, J. Planar Chromatogr., 9, 466 (1996)

[16] S.C. Dhanesar, J. Planar Chromatogr., 11, 195 (1998)

[17] S.C. Dhanesar, J. Planar Chromatogr., 12, 114 (1999)

[18] I. Quintes, J. Eykens, E. Roets, and J. Hoogmartens, J. Planar Chromatogr., 6,181 (1993)

[19] J. Sherma and B. Fried (eds), Handbook of Thin-Layer Chromatography, Marcel Dekker, New York, 1990

[20] D.L. Mays, F.K. Bangert, W.C. Cantrell, and W.G.. Evans, Anal. Chem., 47, 2229 (1975)

[21] F.I. Sengun and Koksal Ulas, Talanta, 33, 363 (1986)

[22] F.I. Sengun and I. Fedai, Talanta, 33, 366 (1986)

[23] P.B. Issopoulos, J. Pharm. Biomed. Anal., 7, 619 (1989)

[24] British Pharmacopeia, Vol. 1, 1980, p. 86

[25] R. Brunner, in R. Brunner and G. Machek (eds), Die Antibiotica Hans Carls, Nuremberg, FRG, (1962), p. 7

[26] J. Ripphahn and H. Halpaap, J. Chromatogr., 112, 7 (1975)

[27] E.J. Vandamme and J.P. Voets, J. Chromatogr., 71, 141 (1972)

Table I

Solvent System used

\begin{tabular}{|l|c|c|}
\hline \multicolumn{1}{|c|}{ Components } & $\mathrm{pH}$ & Abbreviation \\
\hline 0.2 M Boric acid & 1.20 & $\mathrm{~S} 1$ \\
\hline Citrate buffer (0.2 M citric acid + 0.2 M sodium hydroxide) & 3.10 & $\mathrm{~S} 2$ \\
\hline Citrate buffer (0.2 M citric acid + 0.2 M sodium hydroxide) & 4.15 & $\mathrm{~S} 3$ \\
\hline Citrate buffer (0.2 M citric acid + 0.2 M sodium hydroxide) & 5.55 & $\mathrm{~S} 4$ \\
\hline Borate buffer (0.2 M boric acid + 0.2 M sodium hydroxide) & 9.20 & $\mathrm{~S} 5$ \\
\hline Borax & 9.22 & $\mathrm{~S} 6$ \\
\hline Borate buffer (0.2 M boric acid + 0.2 M sodium hydroxide) & 10.23 & $\mathrm{~S} 7$ \\
\hline Aqueous ammonia (30\%) & 13.35 & $\mathrm{~S} 8$ \\
\hline 0.1 M Potassium dihydrogen phosphate & 5.35 & $\mathrm{~S} 9$ \\
\hline
\end{tabular}


Table II

$h R_{\mathrm{f}}$ values of the cephalosporins on stannic arsenate layers developed with different mobile phases

\begin{tabular}{|c|l|c|c|c|c|c|c|c|c|c|}
\hline No. & Cephalosporin & S1 & S2 & S3 & S4 & S5 & S6 & S7 & S8 & S9 \\
\hline 1 & Cephalexin & 87.55 & 72.42 & 11.24 & 77.27 & 94.50 & 84.61 & 87.50 & 43.32 & 44.40 \\
\hline 2 & Cefadroxil & 42.90 & 72.32 & 0.00 & 77.27 & 43.82 & 15.30 & 38.40 & 61.35 & 55.50 \\
\hline 3 & Cefaclor & 99.95 & 87.27 & 76.73 & 85.50 & 99.40 & 99.50 & 97.85 & 71.52 & 52.50 \\
\hline 4 & Cefotaxime & 85.54 & 0.00 & 76.47 & 0.00 & 87.50 & 92.50 & 74.80 & 73.83 & 65.42 \\
\hline 5 & Ceftriaxone & 0.00 & 0.00 & 0.00 & 0.00 & 0.00 & 0.05 & 0.10 & 62.55 & 17.35 \\
\hline 6 & Ceftazidime & 0.00 & 0.00 & 0.00 & 0.00 & 45.00 & 98.45 & 3050 & 74.55 & 71.50 \\
\hline 7 & Cefoperazone & 58.15 & 0.00 & 0.00 & 31.35 & 43.75 & 37.40 & 44.55 & 75.80 & 70.40 \\
\hline
\end{tabular}

Table I

Solvent System used

\begin{tabular}{|l|c|c|}
\hline \multicolumn{1}{|c|}{ Components } & $\mathrm{pH}$ & Abbreviation \\
\hline 0.2 M Boric acid & 1.20 & $\mathrm{~S} 1$ \\
\hline Citrate buffer (0.2 M citric acid + 0.2 M sodium hydroxide) & 3.10 & $\mathrm{~S} 2$ \\
\hline Citrate buffer (0.2 M citric acid + 0.2 M sodium hydroxide) & 4.15 & $\mathrm{~S} 3$ \\
\hline Citrate buffer (0.2 M citric acid + 0.2 M sodium hydroxide) & 5.55 & $\mathrm{~S} 4$ \\
\hline Borate buffer (0.2 M boric acid + 0.2 M sodium hydroxide) & 9.20 & $\mathrm{~S} 5$ \\
\hline Borax & 9.22 & $\mathrm{~S} 6$ \\
\hline Borate buffer (0.2 M boric acid + 0.2 M sodium hydroxide) & 10.23 & $\mathrm{~S} 7$ \\
\hline Aqueous ammonia (30\%) & 13.35 & $\mathrm{~S} 8$ \\
\hline 0.1 M Potassium dihydrogen phosphate & 5.35 & $\mathrm{~S} 9$ \\
\hline
\end{tabular}

Table II

$h R_{\mathrm{f}}$ values of the cephalosporins on stannic arsenate layers developed with different mobile phases

\begin{tabular}{|c|l|c|c|c|c|c|c|c|c|c|}
\hline No. & Cephalosporin & S1 & S2 & S3 & S4 & S5 & S6 & S7 & S8 & S9 \\
\hline 1 & Cephalexin & 87.55 & 72.42 & 11.24 & 77.27 & 94.50 & 84.61 & 87.50 & 43.32 & 44.40 \\
\hline 2 & Cefadroxil & 42.90 & 72.32 & 0.00 & 77.27 & 43.82 & 15.30 & 38.40 & 61.35 & 55.50 \\
\hline 3 & Cefaclor & 99.95 & 87.27 & 76.73 & 85.50 & 99.40 & 99.50 & 97.85 & 71.52 & 52.50 \\
\hline 4 & Cefotaxime & 85.54 & 0.00 & 76.47 & 0.00 & 87.50 & 92.50 & 74.80 & 73.83 & 65.42 \\
\hline 5 & Ceftriaxone & 0.00 & 0.00 & 0.00 & 0.00 & 0.00 & 0.05 & 0.10 & 62.55 & 17.35 \\
\hline 6 & Ceftazidime & 0.00 & 0.00 & 0.00 & 0.00 & 45.00 & 98.45 & 3050 & 74.55 & 71.50 \\
\hline 7 & Cefoperazone & 58.15 & 0.00 & 0.00 & 31.35 & 43.75 & 37.40 & 44.55 & 75.80 & 70.40 \\
\hline
\end{tabular}

